\title{
Economic interpretation of lost due to improper stump-height of trees in Nepal
}

\author{
T. Subedi ${ }^{1 *}$ and M. Ghimire ${ }^{1}$
}

In recent years, import of timber and other wood products from different parts of the world have been increasing in Nepal. The Government of Nepal aims to be a self-sustain in timber production. In this context, the objective of this study was to estimate efficiency of harvesting practices in Nepal in relation to stump-height. We collected the data on the stump-heights and other biometric characteristics of the trees from different felling sites of Kailali, Kanchanpur, Jhapa and Morang districts of Nepal. The volumes of the individual trees as well as the proportions of the volumes of their stumps with different heights were calculated. Correlation and ANOVA were used to find the significance of the associated factors. The average stump-heights using the conventional felling method and the chain saw method were found to be $0.74 \pm 0.17 \mathrm{~m}$ and $0.46 \pm 0.21 \mathrm{~m}$, respectively with wider range. The correlation between the stump-height and diameter at breast height (dbh) was found significant. Similarly, the harvesting method, skill and experience of the tree-fellers and tree species were also found to be significant with the stump-heights. On an average, $5 \%$ of the total timber production equivalent to one million cubic feet (cft) is lost in the Fiscal Year 2074/075 in Nepal while adopting the conventional method of harvesting because of the higher stump-height than the one prescribed by the Government. The estimated loss was NRs. 2 billion (roughly equivalent to US \$20 million, @NRS $100=1$ USD) to the national economy, and the Government had to bear loss of about NRs. 500 million (roughly equivalent to 5 million USD) from the royalty of timber. This amount of loss could be reduced to half by using power chain saw. Lack of skilled laborers, poor implementation of law, and weak knowledge of officials were major causes for losses in harvesting practices. Moreover, about $2 \%$ wood volume loss can be avoided, without any further investment, by setting minimum standard stump-height at $15 \mathrm{~cm}$ and providing training to the field staff and tree harvesters.

Keywords: Conventional method, correlation, harvesting, power chain saw, wood volume

I

n Nepal, forest covers $40.36 \%$ of the total land area of the country, which is almost $10.0 \%$ greater than the global average. On the other hand ,the forest area is lower than the average global per capita forest land available (FAO/UNEP, 2020; DoF 2017; DFRS, 2015). Within this forest area, the average number of stems greater than ten $\mathrm{cm}$ diameter is 430/ha (DFRS, 2015). Moreover, despite increasing efforts of the government and non-government actors, the mean stem volume per unit area of Nepal was decreased (DoF, 2017;DFRS, 2015).

The demand for timber is increasing in Nepal, particularly for post-earthquake reconstruction works. In the Fiscal Year (F.Y.) 2074/075 (2017/018), it was estimated that around 20.7 million cubic feet (cft) timber log was produced while nearly one million cft of sawn timber was imported (KC, 2019; MoFE, 2018). In the same F.Y., approximately NRs. 0.8 billion worth of plywood was imported through the Nepalgunj Custom Office alone. Further, steel and cement are increasingly used as substitutes of forest products (KC, 2019; MoFE, 2018). Thus, a large amount of foreign currency is going outside from the country every year due to lack of wood production. 
Despite higher potentials, wood production in the country is lower due to the lack of proper forest management tool and knowledge. It is estimated that $30 \%$ of value is lost during tree harvesting (Boston \& Dysart, 2000). Small improvements in value recovery can lead to large improvements in the financial performance of forestry investments (Boston \& Dysart, 2000). There have been several studies to compare and improve the productivity during the felling through different methods and tools throughout the world (Boston \& Dysart, 2000; Hall \& Han, 2006; Berch et al., 2012; Han $\&$ Renzie, 2005). These studies have indicated higher stump-height (the lower portion of tree bole left on the ground after felling trees) as one of the major causes of losses of timber volume. Therefore, since 1964 different techniques had been adopted to estimate the value of stumps left in normal harvesting (Boston \& Dysart, 2000). However, there is a dearth of studies aimed at increasing wood productivity through improvement of harvesting technology in Nepal (Shrestha, 2017). Therefore, a suitable harvesting system is needed to enhance wood production (Akay et al., 2006).

In this context, this study aims to investigate the losses of timber volume and their monitory value during logging operations due to higher stumps. In this study, we assessed the average stump-height during the regular forest harvesting operations, evaluated the economic losses due to the prevailing harvesting systems, analyzed the causes of losses, searched the possible value gain during the felling operations, and recommend the attention for future operations. The findings of this study will be useful to develop guidelines for minimizing wood loss and maximizing benefits and improving productivity during timber harvesting operations.

\section{Materials and methods}

The sample trees were selected through purposive sampling covering the trees with all diameter range available in the felling area. Data were collected mainly for volume calculation (Table 1), and average stump height calculation (Table 2). In order to calculate the total volumes of trees and different sections of stumps of the felled trees, 42 samples of Sal (Shorea robusta) and 34 samples of Asna (Terminalia alata) were collected from the felling sites of the Ranijamara Irrigation Project, the Balchaur area of Kailali district and the felling site of the then Timber Corporation of Nepal (TCN), the Bani area of Kanchanpur district and the Manakamana, Hachumasa, Halluwagadh and Jukekhadi CFs of Jhapa district. Species name and diameter at breast height (dbh), diameter at $15 \mathrm{~cm}$ and $30 \mathrm{~cm}$ above ground level of all the sampled trees were recorded before felling. Then, the stump-heights and the over bark diameters along the tree-stem with 0.5 to $2 \mathrm{~m}$ interval up to the tip of the trees were measured using diameter tape after felling the trees (Subedi, 2017). The total volumes of the sampled trees and their stumps were calculated using the Smalian's Formula through the Sectional Method (Subedi, 2017) and stump volume (up to $15 \mathrm{~cm}$ ) were calculated assuming the cylinder. Similarly, $15-30 \mathrm{~cm}$ above ground level, and above $30 \mathrm{~cm}$ to the tip of the individual stumps (left-over after felling) were calculated using the Smalian's Formula. The volume percentages of different sections of the stumps with respect to the total volume of the same trees were calculated. The details of the sampled trees measured in this way are presented in Table 1. In all these areas, harvesting operations were done in March to mid-June using saw and axe following the conventional method.

Table 1: Statistics of the sampled trees for volume calculation (first dataset)

\begin{tabular}{|c|c|c|c|c|c|c|c|c|c|c|}
\hline \multirow[b]{2}{*}{ Species } & \multirow{2}{*}{$\begin{array}{c}\text { No. of } \\
\text { samples } \\
\text { (n) }\end{array}$} & \multicolumn{4}{|c|}{ dbh $(\mathrm{cm})$} & \multicolumn{4}{|c|}{ Total tree height (m) } & \multirow{2}{*}{$\begin{array}{l}\text { Harvesting } \\
\text { method }\end{array}$} \\
\hline & & Av. & $\begin{array}{l}\text { Std. } \\
\text { dev. }\end{array}$ & Min. & Max. & Av. & $\begin{array}{l}\text { Std. } \\
\text { dev. }\end{array}$ & Min. & Max. & \\
\hline $\begin{array}{l}\text { Sal }(S . \\
\text { robusta })\end{array}$ & 42 & 63.77 & 15.13 & 34.0 & 108.5 & 29.4 & 6.12 & 25.0 & 42.1 & Conventional \\
\hline $\begin{array}{l}\text { Asna ( } T \text {. } \\
\text { alata) }\end{array}$ & 34 & 71.83 & 20.24 & 37.9 & 116.3 & 35.7 & 4.0 & 8.0 & 41.2 & Conventional \\
\hline Total & 76 & 67.4 & 17.9 & 34.0 & 116.3 & 32.7 & 6.14 & 8.0 & 42.1 & \\
\hline
\end{tabular}


Secondly, in order to find out the stump-heights and the causes for their heights, the information on the tree species and the stump-heights of the felled trees using saw and axe were collected from the felling sites of Kailali and Kanchanpur districts while the same information on the felled trees using power chain saw were gathered from the Aahale, Ramite, Siddhartha, Sukuna, and Basanta Hariyali CFs and the Latijhoda Collaborative Forest (CFM) of Morang district (Table 2).

Table 2: Statistics of the sampled trees for stump-height measurement (second dataset)

\begin{tabular}{|c|c|c|c|c|c|c|c|}
\hline Species & District & $\begin{array}{l}\text { No. of } \\
\text { samples } \\
\text { (n) }\end{array}$ & $\begin{array}{c}\text { Average } \\
\text { dbh }\end{array}$ & Std. dev. & $\begin{array}{l}\text { Min. } \\
\text { dbh }\end{array}$ & $\begin{array}{l}\text { Max. } \\
\text { dbh }\end{array}$ & $\begin{array}{c}\text { Harvesting } \\
\text { method }\end{array}$ \\
\hline \multirow{3}{*}{ Asna (T. alata) } & Kailali & 11 & 77.6 & 17.41 & 50.9 & 116.3 & Conventional \\
\hline & Kanchanpur & 18 & 73.2 & 19.49 & 41.7 & 115.2 & Conventional \\
\hline & Morang & 17 & 56.6 & 8.92 & 43.3 & 75.1 & Chain saw \\
\hline \multirow{3}{*}{$\begin{array}{l}\text { Karma }(A . \\
\text { cordifolia) }\end{array}$} & Kailali & 3 & 51.2 & 22.98 & 37.9 & 77.7 & Conventional \\
\hline & Kanchanpur & 2 & 88.0 & 17.68 & 75.5 & 100.5 & Conventional \\
\hline & Morang & 22 & 86.8 & 36.75 & 46.4 & 190.4 & Chain saw \\
\hline $\begin{array}{l}\text { Tetrameles } \\
\text { nudiflora }\end{array}$ & Morang & 32 & 79.2 & 40.50 & 37.1 & 166.0 & Chain saw \\
\hline \multirow{2}{*}{ S. robusta } & Kanchanpur & 8 & 61.9 & 14.87 & 42.8 & 90.6 & Conventional \\
\hline & Morang & 43 & 61.9 & 17.31 & 31.4 & 115.1 & Chain saw \\
\hline \multirow[t]{2}{*}{ Others* } & Morang & 5 & 76.2 & 26.03 & 43.2 & 113.0 & Chain saw \\
\hline & $\begin{array}{l}\text { Total/ } \\
\text { Average }\end{array}$ & 161 & 71.1 & 28.07 & 31.4 & 190.4 & \\
\hline
\end{tabular}

* include Albizia spp, L. coromandelica and T. bellirica.

Out of the total 237 sample trees selected, 93 belonged to Sal (S. robusta), 80 belonged to Asna (T. alata), 32 belonged to Maina (Tetrameles nudiflora) and 27 belonged to Karma (Adina cordifolia). Similarly, 2 each belonged to Siris (Albizia spp) and Hallude (Lannea coromandelica) while 1 belonged to Barro (Terminalia bellirica). Among them, 118 trees were felled adopting the conventional method (Table 1 and Table 2) while 119 were harvested using chain saw (Table 2). The data were entered into the Excel Sheet, and analyzed in the R environment ( $\mathrm{R}$ Core Team, 2018).

In addition to the measurements of tree characteristics, 15 groups of tree harvesters, at the aforementioned felling sites, were interviewed with regards to their years of experience and skill in felling trees, their knowledge about legal code on stump-height and physical challenges they used to face during tree felling. Similarly, the officials of the 10 community forest user groups were interviewed regarding their knowledge on tree harvesting technique and legal code.
The data were analyzed using the graphical visualization and statistical test. The Pearson's Product Moment Correlation Test was used for significant correlation with the $\mathrm{dbh}$ and stump-heights of the trees. ANOVA was used to test against the null hypothesis as there was no significant difference in the stump-heights with respect to the species and the laborers' performance at different locations. All the tests and analyses were performed separately for volume calculation data sets (Table 1) and stumpheights data sets (Table 2).

\section{Results \\ Stump-height and dbh using conventional method}

The average stump-height using the conventional method of felling was found to be $0.737 \pm 0.167$ $\mathrm{m}$ (conventional method, of Table 1 and Table 2 ), but $0.697 \pm 0.16 \mathrm{~m}$ was noticed with the range of $0.25-1.2 \mathrm{~m}$ for the first data set, i.e. volume calculation dataset (Table 1). However as per the Government Guidelines (MoFSC, 2016), 
the stump height should not be higher than 30 $\mathrm{cm}$. Figure 1 (a) indicates the positive linear relation of stump-height with the dbh (of volume calculation data set). The correlation between the stump-height and the dbh was found to be moderate $(r=0.5822)$ but highly significant $(\mathrm{df}$ $=74$ and $\mathrm{p}$-value $=3.447 \mathrm{e}^{-08}$ at $95 \%$ confidence level). Around $80 \%$ of the interviewees (tree harvesters) reported that cutting trees at lower stump-height was more time consuming and more physically arduous, and therefore, they preferred to cut trees at higher stump-height. According to them, neither their supervisors nor any officials had provided any instruction regarding stump-height to them in course of tree felling. Though, the average stump-height was much higher, the minimum stump-height showed that there was possibility to cut trees at $25 \mathrm{~cm}$ above ground level using saw and axe. All most informants reported that they were unaware about the standard stump-height.

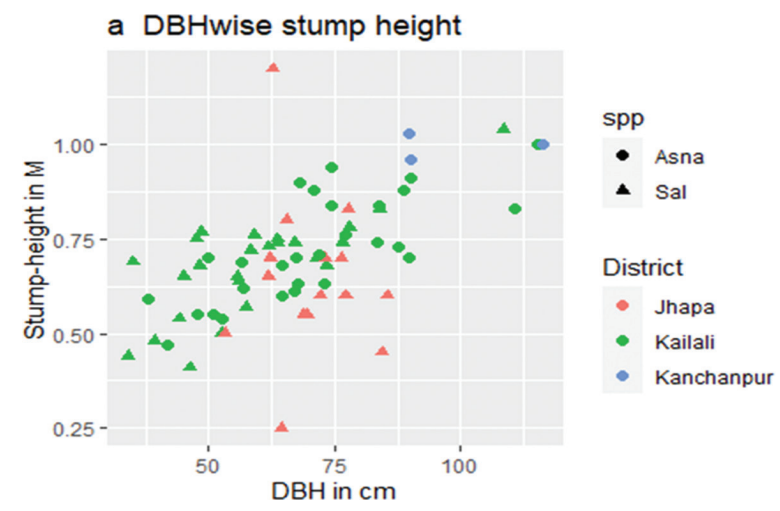

b locationwise stump-height

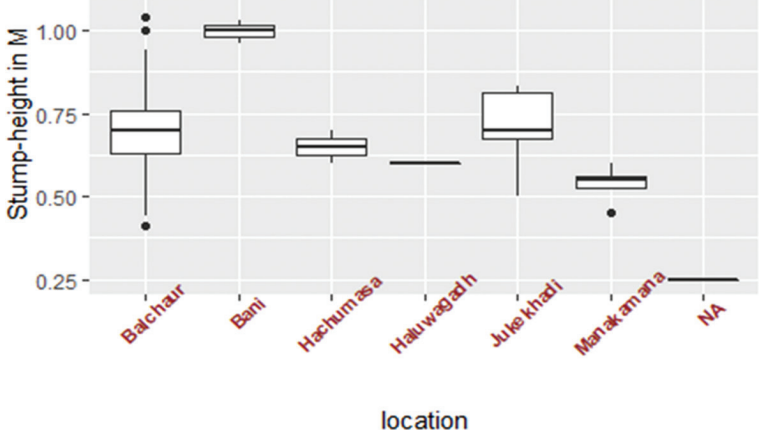

Fig. 1: In conventional method of felling-a) stump-height $(\mathrm{m})$ vs. $\mathrm{dbh}(\mathrm{cm})$ with respect to different tree species and districts; and b) stumpheight (m) vs. harvesters at different locations

\section{Factors associated with stump-height adopting} conventional method of felling

The stump-heights of both the species (S. robusta and $T$. alata) are not so distinguishable up to 75 $\mathrm{cm}$ dbh (Figure 1a); but, in the case of the trees with above $75 \mathrm{~cm}$ dbh, T. alata had higher stumpheight, which might be either due to the perceived lower economic value of the species or difficulty in felling the trees with larger diameter at lower height. However, the difference in the stumpheights between the species was not found to be statistically significant $(\mathrm{p}$-value $=0.0571, \mathrm{df}=74$ ) when using conventional method of felling. No uniformity was noticed in the stump-heights even within the same district. Though, one stumpheight was found to be highest in Jukekhadi $\mathrm{CF}$ of Jhapa district (Figure $1 \mathrm{~b}$ ), the laborers of this district were found to be slightly more efficient (with lower mean stump height)than those of Kanchanpur and Kailali districts. It can be clearly noticed from Figure $1 \mathrm{~b}$ that the tree harvesters from the different places with almost similar terrain condition left over unequal stumpheights. The reason for this is that almost all the tree harvesters hired for the purpose were either inexperienced or not properly trained on tree harvesting.

\section{Stump-height using chain saw}

Figure 2a shows the clear difference in the stumpheights based on the felling methods. The stumpheights of the trees felled using the conventional method of felling were rarely lower than $60 \mathrm{~cm}$ above ground level (Figure 2a). The mean stumpheight using chain saw was found to be $0.46 \pm 0.21$ $\mathrm{m}$ above ground level with the range of $0.05-1.15$ m (Table 3). However, Boston \& Dysart (2000) found that the mean stump-height of the trees felled using chain saw was $20 \mathrm{~cm}$ above ground level which was a bit higher than that of the trees felled using other mechanical means. Han \& Renzie (2005) found that chain saw felling left $19.8 \mathrm{~cm}$ stump-height. Similar type of study in British Columbia found the average stumpheight to be $21.9 \mathrm{~cm}$; the stump-height as per the Government's Guidelines being $30 \mathrm{~cm}$ (Hall \& Han, 2006). In this regard, Pukkala et al. (undated) used the stump-height of $10 \mathrm{~cm}$, Oderwald \& 
Johnson (2009) used $12 \mathrm{~cm}$; Applegate et al. (1985) used $15 \mathrm{~cm}$, and Eerikainen (2001) used $20 \mathrm{~cm}$ as standard stump-heights for total stem volume calculation of trees. They also found that the stump-height as low as $10 \mathrm{~cm}$ above ground level was attainable using chain saw. Fortunately in this study, we found $5 \mathrm{~cm}$ as the lowest stumpheight; however, we noticed a wider range in the stump-heights which could be due to the variation in the capacity and experience of the harvesters using chain saw (Boston \& Dysart, 2000).
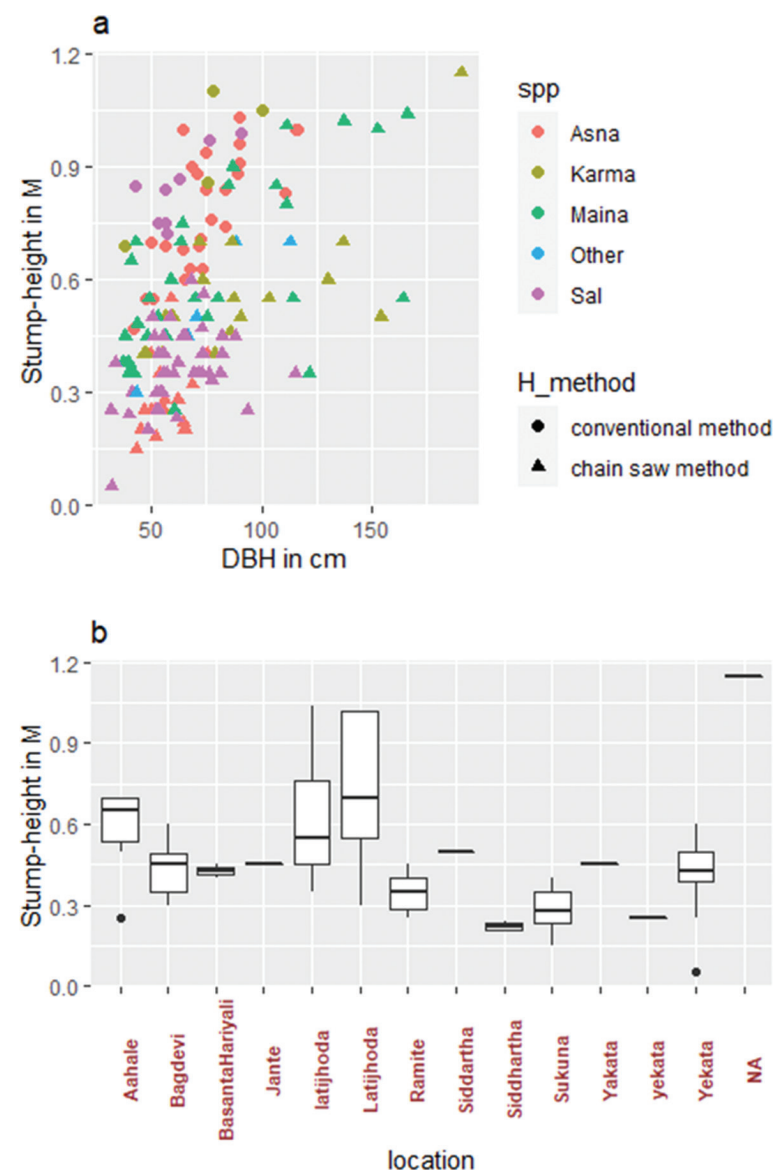

Figure 2: In chain saw method of felling-a) stump-height (m) vs. dbh (cm) with respect to different tree species and harvesting method; and b) stump-height (m) vs. harvesters from different places

When the felling was done using chain saw, the correlation between the stump-height and dbh was found to be higher (0.66) than that using the conventional method. The Pearson's correlation test also showed statistically significant ( $\mathrm{p}$-value $=2.67 \mathrm{e}^{-16}$ and $\mathrm{df}=117$ at $95 \%$ confidence interval).Similarly, the stump-heights were also found significantly different among the species $\left(p=2.4 \mathrm{e}^{-11} ; \mathrm{df}=114\right)$ when using the chain saw method. The detailed statistics of the stumpheights using chain saw among the species are presented in (Table 3). Han \& Renzie (2005) also indicated that stump-height was significantly affected by the species, slope of the felling site, and average stump diameter; however, Keivan \& Ghaffarzadeh (2018) found no significant difference between the different tree diameter classes and stump-heights when the trees were felled using chainsaw, but they found higher stump-height in the higher sloppy areas. Among the tree species, T. nudiflora had higher stumpheight, mainly due to higher diameter range $(>100 \mathrm{~cm})$, larger swellings, buttresses and low economic value. The tree species having larger buttresses such as Karma also had similar stumpheight (Figure 2a). Moreover, the tree harvesters were also found equally important factor for causing variations in the stump-heights. Figure $2 \mathrm{~b}$ clearly shows variation in the stump heights in different locations due to different harvesters.

Table 3: Stump-height using chain saw method

\begin{tabular}{|l|c|c|c|c|}
\hline \multicolumn{1}{|c|}{ Species } & $\begin{array}{c}\text { mean } \\
\text { stump-ht. }\end{array}$ & $\begin{array}{c}\text { Std. } \\
\text { dev. }\end{array}$ & Min. & Max. \\
\hline T.nudiflora & 0.62 & 0.237 & 0.25 & 1.04 \\
\hline S. robusta & 0.36 & 0.103 & 0.05 & 0.60 \\
\hline T. alata & 0.28 & 0.100 & 0.15 & 0.55 \\
\hline A. cordifolia & 0.53 & 0.178 & 0.25 & 1.15 \\
\hline Others & 0.53 & 0.172 & 0.30 & 0.70 \\
\hline $\begin{array}{l}\text { Av. } \\
\text { stump- } \\
\text { height }\end{array}$ & $\mathbf{0 . 4 6}$ & $\mathbf{0 . 2 0 8}$ & $\mathbf{0 . 0 5}$ & $\mathbf{1 . 1 5}$ \\
\hline
\end{tabular}

Most of the tree harvesters using chain saw were paid on the basis of the quantity of the harvested timber; therefore, they wanted to cut trees at lower stump-height if the trees were not twisted and devoid of buttress; the reason for higher stumpheight, according to the tree-fellers, was that the trees to be felled were already stamped (locally known as "chhapan") at higher height, and they were instructed to cut the trees above the stamped portions so that the stamps were visible on the left-over stumps for the purpose of monitoring. Then, in course of our field observation, such stamp-marks were mostly noticed around 25 $\mathrm{cm}$ above ground level, which is against the Government's rule of stamping the trees to be felled within $15 \mathrm{~cm}$ above ground level (MOFSC, 2016). The harvesters described that cutting trees at higher heights were easy in the case of the 
trees with buttresses or twisted stems. A few experienced tree harvesters opined that it was feasible to cut trees as below as $10 \mathrm{~cm}$ above ground.

During the interviews with the concerned $\mathrm{CF}$ officials, it was revealed that they were unaware about the loss of wood-volume owing to cutting of trees at higher heights. Only after convincing them the truth, they accepted
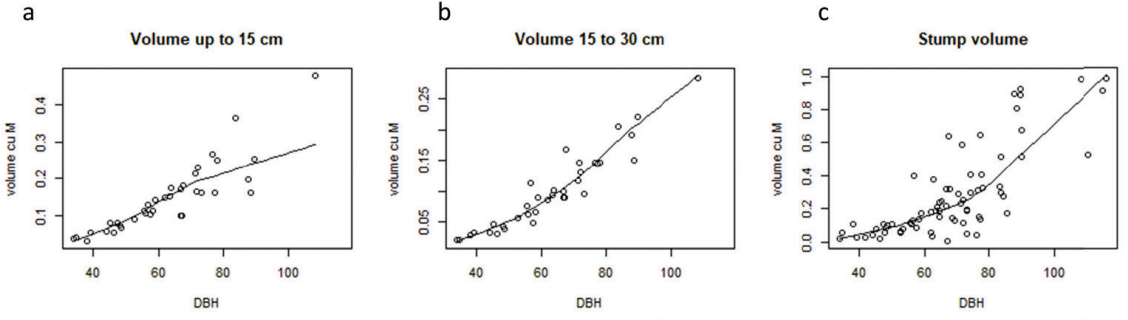

d

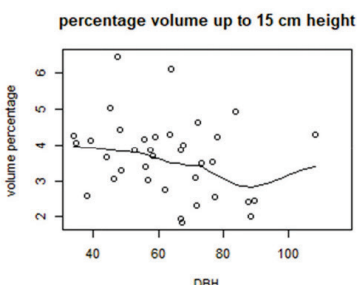
e
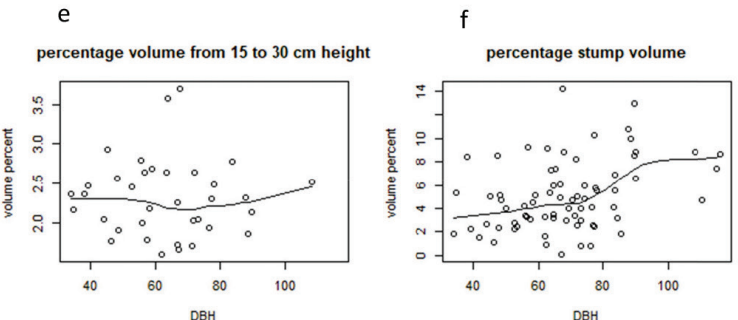

Fig. 3: Absolute volume of the stumps up to different heights (a, b, c), and their percentage as compared to the volumes of the whole trees $(\mathrm{d}, \mathrm{e}, \mathrm{f})$

be put at heights lower than $15 \mathrm{~cm}$ above ground even in the sloppy areas. However, Boston \& Dysart (2000) argued that large range of stumpheight is questionable to the skill and experience of the tree harvesters though in difficult situation, their safety should not be jeopardized for attaining lower stump-height.

\section{Discussion}

\section{Stumps percentage of the total tree volume}

We assumed that the stumps with the lowest height of $15 \mathrm{~cm}$ above ground level were not achievable; however, the absolute mean wood volume of the stumps up to $15 \mathrm{~cm}$ above ground level was found to be $0.1476 \mathrm{~m}^{3}$ (Figure 3a) which was $3.65 \%$ of the total stem volume (Figure $3 d$ ). Similarly, the absolute mean wood volume of the stumps within the range of $15-30 \mathrm{~cm}$ height above ground level was $0.1007 \mathrm{~m}^{3}$ (Figure 3b) which was $2.32 \%$ with the range of $1.60-3.70 \%$ of the total stem volume of the trees (Figure $3 \mathrm{e})$. Based on the above discussion with the harvesters and the CF Officials, this proportion of wood can be achievable through efficient management and trained workers. Likewise, the mean wood volume of the stumps from $30 \mathrm{~cm}$ height above ground level to the tip of the stump $(\mathrm{n}=72)$ was $0.148 \mathrm{~m}^{3}$ (Figure $3 \mathrm{c}$ ) equivalent to $5.07 \%$ with range of $0.04-14.20 \%$ of the total stem volume (Figure $3 \mathrm{f}$ ). This is absolutely lost due to inefficient management and only partially obeys the rule. The absolute stump volume of the higher than $30 \mathrm{~cm}$ height above ground level were found to have gradually increased up to 80 $\mathrm{cm} \mathrm{dbh}$, and then increased more sharply in the cases of the trees with over $80 \mathrm{~cm}$ dbh (Figure 3c) which could be possibly due to the reason that the trees with larger dbh (above $80 \mathrm{~cm}$ ) might have higher stump-height and might be butt-swelling (Figure 3a), especially in the cases of T. alata, A. cardifilia and T. nudiflora.

The study indicates that, on an average, $5.07 \%$ of the timber volume was lost through conventional method of felling due to the stumpheight which was more than the prescribed by the Government (MoFSC, 2016). In the Fiscal Year 2074/075, about 20.7 million cft of timber wood were produced in Nepal (KC, 2019); thus, the amount of wood loss, owing to the felling of trees adopting the conventional method, was expected to be 1 million cft. Coincidently, about 1 million cft of sawn timber was imported from different countries in the same FY (KC, 2019). Assuming the rate of timber to be NRs. 2,000 per $\mathrm{cft}$, there was a loss of NRs. 2 billion (roughly equivalent to 20 million USD @ of NRs.100= 1USD) to the national economy. On the other hand, the Government had to bear a loss of about NRs. 500 million from the royalty of timber if we assume the royalty rate of NRs 500 per cft or about NRs 300 million if we assume only $15 \%$ of the market price. This amount of loss could be reduced to half by using power chain saw since the average stump height (using chain saw) above the prescribed height is found more than half than the conventional method. About $2 \%$ of the further timber volume can be produced without any 
further investment through setting the standard stump height as $15 \mathrm{~cm}$ and strictly follow the government code and using power chain saw. In addition to this direct financial benefit, there was a loss of other ecological and climatic benefits, e.g. reduction of emission in the decaying process of stumps (Hall and Han, 2006). Lack of effective implementation of legal codes and hiring inexperienced laborers for felling of trees had resulted in the loss; however, it is to be noted that the Government's legal codes have clearly prohibited the hiring of untrained or inexperienced laborers for tree harvesting operations (MoFSC, 2016). Awareness raising and capacity building of the laborers and officials in operating power chain saw together with effective implementation of the legal codes will help to attain the national target for self-sustaining in timber production. However, as it is feasible to fell trees as below as $10 \mathrm{~cm}$ above ground level, felling trees within $15 \mathrm{~cm}$ above ground level is likely to increase timber production by $2.0 \%$ without any further investment.

\section{Conclusion and recommendations}

The harvesting method was found major determinant factor of higher stump heights. The average stump-height of the trees was found to be $0.74 \pm 0.17 \mathrm{~m}$ and $0.46 \pm 0.21 \mathrm{~m}$ through conventional harvesting method and power chain saw method, respectively. The stump-heights were found to be significantly correlated with the $\mathrm{dbh}$ of the trees in both the cases. However, the stump-heights were found to be affected by the species when the trees were felled by power chain saw. Though the absolute volumes of the stumps were directly related to the size of the trees, their percentage volumes were not affected by their sizes.

Nepal lost, on an average, $5 \%$ of the total timber volume per tree due to the higher stump-height than the one set by the Government, leading to the loss of one million cft wood through conventional harvesting in the FY 2074/075.The wood production throughout the nation can be improved by lowering the stump-height of the trees to be felled. This amount of loss could be reduced to more than half by using power chain saw. There is possibility of producing about $2 \%$ more timber volume by setting new standard and strictly following the government code. The major causes for higher stump-heights were the physical difficulties, weak knowledge and weak monitoring of the conventional felling method. In addition to this, stamping the felling-marks (on the trees) at higher heights, lack of experience and skill of tree harvesters and weak enforcement of the Government's Guidelines in the field are other major determinant factors for the same. The mean stump-height can be significantly reduced by setting new harvesting code in addition to strictly adhering to the Government's felling norms, adopting chain saw method of felling instead of the conventional method, providing necessary trainings to the concerned field technical staff and tree harvesters.

\section{Acknowledgements}

I acknowledge Dr. B. Pasakhala, International Centre for International Mountain Development (ICIMOD), Kathmandu, for his valuable comments and suggestion since course of the preparation of this manuscript and Mr. K. K. Pokharel, Managing Editor of Banko Janakari for encouraging me to bring it into this stage.

\section{References}

Akay, E. A., Yilmaz, M. \& Tonguc, F. (2006). Impact of mechanized harvesting machines on forest ecosystem: Residual stand damage. Journal of Applied Sciences 6 (11): 2414-2419.

Applegate, G. P. Hawkins, T. \& Thompson, I. (1985). Preliminary Guidelines for Biomass Studies in Nepal. Technical Note 2/85. Nepal Australia Forestry Project II; Nepal/UK Silvicultural Research Project, Forest Research Information Centre, Kathmandu, Nepal.

Berch, S. M., Curran, M., Dymond, C., Hannam, K., Murray, M., Tedder, S., Titus, B. \& Melissa T. (2012). "Criteria and Guidance Considerations for Sustainable Tree Stump Harvesting in British Columbia". Scandinavian Journal of Forest Research 27 (8): 709-23.

Boston, K. \& Dysart, G. (2000). A Comparison of Felling Techniques on Stump-height and Log Damage with Economic Interpretations. Western Journal of Applied Forestry 15 (2) : 59-61. 
DFRS. (2015). State of Nepal's Forests. Government of Nepal, Ministry of Forests and Soil Conservation, Department of Forest Research and Survey (DFRS), Kathmandu, Nepal.

DoF. (2017). Silviculture for Forest Management. Procedings of the First National Silviculture Workshop. Department of Forest (DoF), Kathmandu, Nepal.

Eerikainen, K. (2001): Stem volume models with random coefficients for Pinus kesiya in Tanzania, Zambia, Zimbabwe. Canadian Journal of Forest Research 31: 879-888.

FAO/UNEP. (2020). The State of the World's Forests 2020. Forests, biodiversity and people. Rome. https://doi. org/10. 4060/ ca8642en

Hall, R. \& Han, H. (2006). Improvements in Value Recovery through Low Stump-heights: Mechanized versus Manual Felling. Western Journal of Applied Forestry21 (1): 33-38.

Han, H. \& Chad, R. (2005). Effect of Ground Slope, Stump Diameter, and Species on Stump-height for Feller-Buncher and Chainsaw Felling. International Journal of Forest Engineering16 (2) : 81-88

KC, R. (2019). Situation Analysis of Scientific Forest Management in Nepal. Hamro Ban 2074/075, Department of Forest and Soil Conservation, Kathmandu Nepal.

Keivan Behjou F. \& Ghaffarzadeh Mollabashi O. (2018): Effects of tree diameter and some working conditions on residual stump height following selective logging - Short Communication. J. For. Sci., 64 : 91-95.

MoFSC. (2016). Forest Products Collection and Distribution Directives. Ministry of Forests and Soil Conservation, 2073, Singhadarbar, Kathmandu, Nepal
MoFE. (2018). White Paper of Forest and Environmental Sectors. Government of Nepal, Ministry of Forests and Environment, 2075, Kathmandu, Nepal.

Oderwald, R. G. \& Johnson, J. E. (2009). Measuring Standing Trees and Logs. https://pubs. ex ext. vt. edu/420/420560/420-560 pdf. 420-560.

Pukkala, T., Sharma E. R. \& Rajbhandari, M. D. (undated). A Guide to Biomass Modeling for Forest Inventory in Nepal. Forest Survey and Statistics Division, Publication No. 51.

R Core Team. (2018). R: A Language and Environment for Statistical Computing. R Foundation for Statistical Computing, Vienna, Austria. URL http://www. R-project. org/.

Shrestha, R. B. (2017). Tree Harvesting in Nepalese Forestry: Practice and Challenges, Silviculture for Forest Management. Proceedings of the First National Silviculture Workshop, 19-21 February, 2017. Department of Forest, Kathmandu, Nepal. 458-466.

Subedi, T. (2017). Volume models for Sal (Shorea robusta Gaertn.) in far-western Terai of Nepal. Banko Janakari 27 (2): 3-11. https://doi. org/10. 3126/banko. v27i2. 21218. a 